be rigorously degassed. Significant measurements in a large number of pure gases with a variety of ions of known types were thus made, and effects due to the attachment of molecules of polar impurities, such as had vitiated the early work, were clearly demonstrated. It was for this work that in 1933 he was elected a Fellow of the Royal Society. Tho main results of these studies were described by Tyndall in a monograph on The Mobility of Ions in Gases.

Even moro important than 'Tyndall's scientific work was his contribution to the foundation and development of the Henry Horbert Wills Physical Laboratory. It is a long and fascinating story which began with his daily walk to the Laboratory in the company of the donor. The original intention was to build a small structure to house a badly needed new battery; but with tho growth of mutual confidence, the programmo was enlarged, and it eventually lod to tho gift of the present building.

At the formal opening of the spacious new Labor. atory, Tyndall was warned by some of the eminent visitors that what makes a good laboratory is not bricks and mortar alone, but the quality of the men in it. He sometimes referred to this incident with a trace of irony, but it was indeed largely owing to his remarkable personal qualities that the Laboratory developed and flourished. Ho created an atmosphere of ease and warrn humanity which helped people to do their bost, and he showed a constant disinterestod solicitude that the work of his colleagues and students should receive proper recognition.

It scems unlikely that in modern conditions in Great Britain another laboratory will again owe so much in its foundation and development to a single man. Cortainly British physics will owe him a debt for a long time to come for the example which he set and for his influence on his colleagues and pupils who included, to name only a few, L. P. Bates, C. IR. Burch, F. C. Frank, H. Fröhlich, R. W. Gurnoy, W. Heitler, W. Herzberg, L. C. Jackson, J. E. LennardJones, H. London, A. C. B. Lovell, N. F. Mott, S. H. Piper, H. W. B. Skinner and W. Sucksmith.

$$
\text { C. F. Powklt }
$$

\section{Dr. W. B. Turrill, O.B.E., F.R.S.}

THE sudden death of Dr. W. B. Turrill, who collapsed and died in his house at Richmond on Decembor 15, 1961, has removed one whose rocord of achievoment placed him fairly in the lino of succes. sion of great Kew botanists. For more than fifty years ho was activoly associated with the Royal Botanic Gardens to which he gave dovotod sorvice and gained wide recognition and high distinction.

Turrill was born at Woodstock on June 14, 1890, and thore is no doubt that in his boyhood ho drow inspiration and delight from the countryside around him which afforded fruitful hunting and excellent training for his bent towards natural history. Ho was odueated at Oxford High School whero he was a contemporary of Lawrence of Arabia of whom he had vivid recollections. When he was sixteen ho started work in the Fielding Herbarium of the University of Oxford and here, with thes specinl cncouragement of the late Dr. (*. Claridge I)ruce and under the guidanee of symprathetic collcagues, Dr. 'Turrill's lovo of plants was greatly stimulated and his botanical ambitions wore fired. 'Three yoars lator, in 1909, he entered the Kew Herbarium as a technical assistant, and in sorting and handling specimens from all ovor the world under the supervision of the leading botan- ists he acquired an excellent knowledge of all plant groups and a reputation for concontrated and thorough work. In his first year at Kew he published his first botanical paper and, except for two years during his military service, he maintained a steady and incroasing flow of publications right up to the time of his death. In all ho was rosponsible for more than 500 published botanical contributions.

During his early years at Kew, Turrill attended classes in botany at the Chelsoa Polytechnic and these studies led to the degree of B.Sc. with first-class honours in botany in 1915 , followed by the M.Sc. in 1922 and eventually the D.S\% in 1928, the last. for his extensive studies of the plant-life of the Balkans.

In 1915 he became a permanent member of the Kow staff, but his career was soon interrupted when he joined the Forces and was sent on active service to Macedonia. It was there that he made his first arquaintance with a new flora, and this experience dotermined his main botanical interest. Whenever he could escape from his military duties he engaged in plant collecting and in a close study of tho vegetation around him. Only after the First World War was he able to make sevoral expeditions to other parts of the Balkans and the consolidated rosults wero published in his magnum opus, T'he Plant-Life of the Balkan Peninsula in 1929, a work which established his reputation as the leading authority on tho flora of south-east Europe.

At Kow he was placed in charge of various plant families including the Cyporaceae, of which he gained an expert knowledge, but latterly he became botanist in charge of the European Mediterranean collections. From his close observation of plants in the field and in the experimental garden, Turrill was convinced that for proper taxonomic understanding comprehonsivo and intensive studies of living and herbarium material was necessary. He developed this theme in a long succession of publications and lectures of which the most notable contributions were the two volumes written in collaboration with the lato $\mathrm{E}$. $\mathrm{M}$. Marsden-Jones on British Knapweeds (1954) and Bladder Campions (1957). He also published extonsively on Ranunculus, Saxifraga and Taraxacum, and his studies on the British flora culminated in his British Plant Life (1948). Other notable works were his Pioneer Plant Geography (1953), The Royal Botanic Gardens, Kew (1959) and Vistas in Botany (1959) which he devised and cdited on the occasion of the bicentenary of Kow. In 1946, Turrill was appointed keeper of the Herbarium and Library, and he held that position until his retirement in 1957.

'Turrill's knowledge, derived from his personal researches and very wide reading, was armazingly extensive and he dolighted in discussion on all kinds of botanical topics with tho many experts who habitually visit Kew. He was also a gifted teacher and for a time he lectured in the evenings at Chelsea. Yolytechnic on evolution, horedity and ecology, and for many years he taught these subjects to the student gardeners at Kew.

T'urrill's outstanding sorviees to his scienco were fitly rocognized in 1958 when ho was admitted to the fellowship of the Royal Society and when, in the same year, he recoived from the Linnoun Society the Linnean Gold Medal. He was honoured by the Royal ITorticultural Society for his active interest in horticulture, particularly for his work on Lilium and Fritillaria, and he also edited Curtis's Rotanical 
Magazine for the Society. In 1953 he was awarded the Veitch Memorial Gold Medal and in 1956 the Victoria Medal of Honour, the Society's highest award. He gained the O.B.E. in 1955 .

Until the last two years of his life Turrill belied his years both by his comparatively youthful appearance and by his activities. He was good-humoured and generous in helping those less gifted than himself. Recreation, apart from reading, seemed to $\operatorname{com} \theta$ from change of work and his remarkably full life would have been impossible but for the devoted and constant companionship of his wife (née Florence Emily Homan), whom he married in 1918 and for whom much sympathy will be felt.

George TAyLor

\section{Mr. Charles S. Durst}

Charles S. Durst was born in 1888. After graduating in mathematics at Pembroke College, Cambridge, in 1910, he worked in Malaya as a surveyor, but on the outbreak of the First World War joined the Royal Engineers, with whom he served in the Middle East. $\mathrm{He}$ came to the Meteorological Office in 1919, and was posted to the Marine Branch, where he helped to set up the world's first punchedcard installation for dealing with meteorological statistics. In 1928 he moved to Cardington to take part in the broad programme of investigations necessitated by the Empire Airship Scheme. The death of his superintendent, M. A. Giblett, in the $R 101 \mathrm{crash}$ left Durst with the task of winding up the programme, and he was the leader of the team which produced the massive Geophysical Memoir No. 54, "The Structure of Wind over Level Country", based on experimental work done at Cardington, a separate section of which was devoted to Durst's own theory of eddies.
After an interval as a forecaster, he was placed in charge of a newly created Special Investigations Branch in 1940, and was able to devote the rest of his working life to the kind of study which best suited him. The main body of his work was of the pattern set by his period at Cardington, and was concerned with such topics as aerial navigation, the climatology of air routes, and the effects of turbulence on aircraft; but he also studied such diverse subjects as the efflux of gases in mines, the structure of wind associated with fronts, the meteorology of radio propagation, vector statistics, and friction at the Earth's surface. His pioneer work on statistical methods of forecasting has had a profound effect on forecasting methods in Britain; it also gave him great entertainment, for he had a lively sense of humour and enjoyed demonstrating how closely his procedures could rival the more elaborate and laborious methods of the synoptic forecaster.

Durst retired from the Meteorological Office in 1957, but continued active as a private consultant. His success in so many fields was based on his genius for handling intractable data. No masses of observation, however unreliable or heterogeneous, daunted him. Indeed, he liked to surround himself with dusty piles of papers so enormous that on entering his room one could rarely see whether he was there or not. But he worked with great patience, concentration, and a quick eye for essentials, and somehow managed to extract his solutions surprisingly quickly. $\mathrm{He}$ was the kindliest of men and, though he was rather hesitant of speech, his humour and the acuteness of his observation made him a most entertaining companion.

Durst died suddenly on Christmas Day 1961. $\mathrm{He}$ leaves a widow, née Mary Helen Blakiston, whom he married in 1921, and a son and daughter.

B. C. V. ODDie

\section{NEWS and VIEWS}

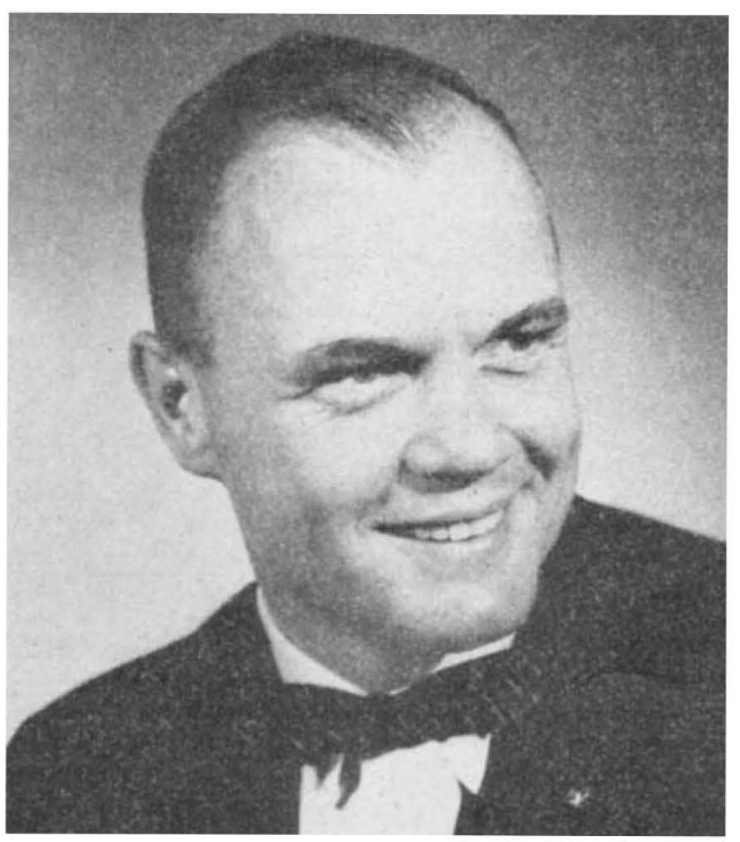

Lieutenant-Colonel John H. Glenn

\section{The First American Manned Earth-Satellite}

ON February 20 at 14.47 U.T. the Atlas $D$ rocket was successfully launched from Cape Canaveral carrying the first U.S. astronaut, Lieutenant-Colonel John Glenn of the U.S. Marines, in the Mercury capsule, Friendship VII (see also p. 807 of this issue). The satellite, which weighed $2,970 \mathrm{lb}$. $(1,350 \mathrm{kgm}$.$) , excluding its rocket booster, was$ projected into an orbit inclined at $32.5^{\circ}$ to the equator, and having an orbital period of $88.6 \mathrm{~min}$. Its height above the Earth varied between 100 and 162 miles (161 and $261 \mathrm{~km}$.). The satellite, designated $1962 \gamma 1$, made three revolutions around the Earth: its deceleration by retro-rocket began west of Los Angeles at about 19.20 U.T. and it descended safely into the Atlantic some 200 miles north-west of Puerto Rico at 19.43 U.T. after a flight of $296 \mathrm{~min}$. The Atlas rocket booster $1962 \gamma 2$ remained in orbit for about nine revolutions. During the voyage Colonel Glenn was able to keep in touch with his fellow astronauts at various tracking stations around the world, and people in many countries were able to listen to him by radio. On his return Colonel Glenn gave an account of his experiences and reactions. On February 23, he, and Dr. Gilruth, director of the project Mercury, were decorated at Cape Canaveral with the Distinguished Service Medal of the National Aeronautics and Space Administration. 